\title{
Concentrated beta-galactosidase and cell permeabilization from Saccharomyces fragilis IZ 275 for beta-galactosidase activity in the hydrolysis of lactose
}

\author{
Luiz Rodrigo Ito MORIOKA ${ }^{1 \star}$ (D), Caroline dos Santos VIANA ${ }^{1}$, Érika de Pádua ALVES ${ }^{1}$, \\ Fernanda Gonzales PAIÃO ${ }^{1}$, Anderson Massaro TAKIHARA², Amanda Sayuri Senoo KAKUNO ${ }^{3}$, \\ Hélio Hiroshi SUGUIMOTO ${ }^{1}$
}

\begin{abstract}
The cheese whey shows an organic nutrient charge that can be used to obtain metabolites of interest by biotechnology of microorganisms. Thus, fermentative processes for enzyme production, in particular beta-galactosidase becomes feasible. The enzyme plays an important role in the biotech food industry to obtain milk and dairy products with low lactose content for consumption by intolerant individuals. The objective of this work was to determine the enzyme activity of the concentrated beta-galactosidase (CBG) and the permeabilized cells (PC) both obtained from Saccharomyces fragilis IZ 275. The enzyme beta-galactosidase obtained from the fermentation of Saccharomyces fragilis IZ 275 in cheese whey was used to determine the optimal conditions for the hydrolysis of lactose solution at 1\% (w/v). Response Surface Methodology (RSM) by Box-Behnken Design (BBD) was employed to determine beta-galactosidase activity for such factors $\mathrm{pH}$, temperature and enzyme concentration suitable for the lactose hydrolysis. Based on the statistical analysis, the optimum operational conditions for maximizing lactose hydrolysis thus optimizing the enzyme activity for $\mathrm{CBG}$ were, temperature $30^{\circ} \mathrm{C}, \mathrm{pH} 6.0$ and enzyme concentration $3 \%(\mathrm{v} / \mathrm{v})$ and for PC was temperature $44^{\circ} \mathrm{C}, \mathrm{pH} 7.0$ and enzyme concentration $4 \%(\mathrm{v} / \mathrm{v})$.
\end{abstract}

Keywords: enzyme activity; microbial biotechnology; cell permeabilization; lactose hydrolysis; enzyme extraction.

Practical Application: Characterization of the appropriate conditions for the enzymatic activity

\section{Introduction}

Cheese whey is the resulting yellow colored liquid from the separation of milk caseins during the cheese-making process. In the past, cheese whey was considered an unusable residual liquid or used as feed for cattle. It is a potentially polluting by-product produced by the dairy industry (Ordoñez, 2005; Florêncio et al., 2013). Nowadays, dairy industry has invested in the research and development in order to transform milk-based products in products with low lactose content (Di Serio et al., 2003; Roy \& Gupta, 2003).

The use of cheese whey in the fermentation makes it possible to generate products of higher value, since it is rich in carbohydrate and minerals, in turn nutritious for microorganisms producing ethanol, enzymes and other metabolites with commercial value (Florêncio et al., 2013; Colognesi et al., 2017). Lactose is the main component of cheese whey making an average of $5 \%(\mathrm{w} / \mathrm{v})$. Thus, cheese whey could be used as an abundant and renewable raw material for microbial fermentations, with lactose providing the carbon source, to obtain the enzyme beta-galactosidase (Domingues et al., 2010).

Saccharomyces fragilis is a homothallic and hemiascomycetous yeast which produce several enzymes among them beta-galactosidase (Dagbagli \& Goksungur, 2008). The major common feature of
S. fragilis is the capacity to metabolize lactose in the production of beta-galactosidase enzyme. Beta-Galactosidase (EC 3.2.1.23) is responsible for the hydrolysis of lactose to glucose and galactose (Torres \& Batista-Vieira, 2012). Thus the cheese whey, source of lactose, can be used as a culture media for obtaining the enzyme (Marcel \& Passos, 2011).

Lactose hydrolyze can be catalyzed by different form which include acids, cationic resins or enzymatic processes (Hatzinikolaou et al., 2005). Lactose hydrolysis by enzymatic process i.e. by the enzymatic activity of beta-galactosidase, work well in a relatively broad $\mathrm{pH}$ and temperature range and does not cause bad flavors, odors and colors. Generally, beta-galactosidase from yeast act between $\mathrm{pH}$ 6.0-7.0 but, depending on the natural source where lactose is present, $\mathrm{pH}$ values range between 3.5-5.6 in acid cheese whey to 6.5 in milk (Demirhan et al., 2010; Şener et al., 2006; Husain, 2010).

The RDC Resolution 205/2006, points out that the beta-galactosidase enzyme used in the dairy industry should be of microbial origin, from the following microorganisms: Aspergillus Niger, Aspergillus oryzae, Candida tropicalis, Kluyveromyces lactis, Kluyveromyces flagilis, Kluyveromyces marxianus, Saccharomyces sp (Brasil, 2006) these species are 
classified as safe by the Food and Drug Administration (FDA), which was an important criterion for food applications (Ansari \& Satar, 2012). The enzyme activity of the beta-galactosidase usually depends on the lactose hydrolysis reaction conditions.

The dairy industry has been develop low lactose or lactose-free products. Thus, lactose hydrolysis from the yeast beta-galactosidase, becomes as biotechnological process with a broad commercial application (Dutra Rosolen et al., 2015). In this context, the objective of this study was to determine the enzymatic activity of the concentrated beta-galactosidase and permeabilized cells obtained from Saccharomyces fragilis IZ 275 cultivated in $5 \%(\mathrm{w} / \mathrm{v})$ cheese whey. The parameters evaluated were the influence of $\mathrm{pH}$, temperature and concentration of enzyme in the hydrolysis of the $1 \%$ lactose solution.

\section{Materials and methods}

\subsection{Microorganism Maintenance, Inoculum and Cultivation}

The yeast Saccharomyces fragilis IZ 275 (SF IZ 275) from the Dairy Science and Technology Center of University Pitagoras Unopar (Brazil) was used in this study. The yeast stock was maintained at $-20^{\circ} \mathrm{C}$ on Potato Dextrose Agar (PDA), pH 5.5, at $30^{\circ} \mathrm{C}$ for 10 days. For the inoculum, before each experiment, cells were transferred and grown at $35^{\circ} \mathrm{C}, \mathrm{pH} 5.5$ for $24 \mathrm{~h}$ on malt extract (15 g/L). Optical density (O.D.) was determined at a wavelength of $570 \mathrm{~nm}$ using a spectrophotometer and at O.D. adjusted to 0.6. The SF IZ 275 was used as inoculum for beta-galactosidase production using cheese whey as media. Cheese whey 5\% (w/v) obtained from Cativa Agroindustrial Cooperativa Central', Londrina, Parana, Brazil was used as media and it was deproteinized by heating at $90{ }^{\circ} \mathrm{C}(\mathrm{pH} 4.6)$ for 30 minutes. Then it was filtered through Whatman $n^{\circ} 1$ filter paper to remove coagulated protein and adjusted to $\mathrm{pH}$ 5.0. It was pasteurized under $65^{\circ} \mathrm{C}$ for 30 minutes. The pasteurized whey was inoculated with $10 \%$ inoculum (at $\left.\mathrm{DO}_{670 \mathrm{~nm}}=0.6\right)$ of SF IZ 275 strain and incubated at $35^{\circ} \mathrm{C}, 150 \mathrm{rpm}$ for 24 hours. At the end of incubation, cells were harvested by centrifugation at $9000 \mathrm{rpm}$ for 20 minutes. The pellets were washed twice with $0.1 \mathrm{M}$ potassium phosphate buffer ( $\mathrm{pH}$ 6.8) solution and stored in $0.1 \mathrm{M}$ phosphate buffer. Since beta-galactosidase from SF IZ 275 is an intracellular enzyme, the cells were permeabilized with ethanol according to the process below.

\subsection{Enzyme concentration}

The extraction of the enzyme, to obtain the concentrate beta-galactosidase, from the previously grown cells of SF IZ 275 was carried out as follows: concentrated biomass was re-suspended in $0.1 \mathrm{M}$ potassium phosphate buffer ( $\mathrm{pH} 6.8$ ), $150 \mathrm{rpm}, 25^{\circ} \mathrm{C}$, with addition of chloroform $2 \%(\mathrm{v} / \mathrm{v})$ and overnight. Immediately, a tangential flow filtration (Millipore, USA) was performed with a membrane porosity of $0.2 \mu \mathrm{m}$ for removal of autolyzed cell. The supernatant (permeate) containing the beta-galactosidase it was ultra-filtrated (membrane of $30 \mathrm{Kda}$ ) to obtain the concentrated enzyme.

After the tangential flow ultrafiltration, the concentrated enzyme was re-suspended in $0.1 \mathrm{M}$ potassium phosphate buffer
(pH 6.8) and stored in amber vial under refrigeration until ready to use.

\subsection{Cell permeabilizaiton}

Cell permeabilization was performed according to Morioka et al. (2016). Previously grown cells were collected by centrifugation $\left(5000 \mathrm{rpm}\right.$ for $10 \mathrm{~min}$ at $10^{\circ} \mathrm{C}$ ) and washed twice with distilled water. Cell permeabilization was done in $20 \mathrm{~mL}$ test tubes each containing a final volume of $5.0 \mathrm{~mL}$ of the reacting suspension consisting of ethanol (35\%) - v/v, SF IZ 275 cells $-50.0 \mathrm{mg}$ (dry weight) and $0.1 \mathrm{M}$ potassium phosphate buffer, $\mathrm{pH}$ 6.8. Tubes were incubated at $20^{\circ} \mathrm{C}$ temperature for 20 minutes. The supernatant was removed by centrifugation for further analysis, and the cells were washed twice with the same buffer. The final pellet was resuspended in $1 \mathrm{~mL}$ of buffer, and the beta-galactosidase activity of permeabilized cells determined as described later.

\subsection{Beta-Galactosidase activity}

For the determination of beta-galactosidase activity it was use the enzymatic colorimetric method of glucose-oxidase. The determination of the enzymatic activity was performed in assay tube containing $10 \mathrm{~mL}$ of lactose solution (1\%) in $0.1 \mathrm{M}$ potassium phosphate buffer $\mathrm{pH} 6.8$. It was added $1 \%(\mathrm{v} / \mathrm{v})$ of the enzyme extract in the tube containing the $1 \%$ lactose solution and incubated at $37^{\circ} \mathrm{C}$ for $18-24$ hours. Samples were placed in boiling water bath for 10 minutes to inactivate the enzyme. After that, the glucose ( $\mathrm{mg} / \mathrm{dL}$ ) concentration was measured by glucose oxidase method using a glucose determination kit for the colorimetric enzymatic method - Glucose kit (Bioliquid ${ }^{\circ}$, Brazil) according to the manufacturer's guidelines.

Calculation of beta-galactosidase activity was according by the method of initial rates of hydrolysis reaction of lactose using Equation 1:

$\mathrm{EA}=\frac{\mathrm{SGC}}{180} \times 1000 \div \mathrm{HT}$

Where:

EA = Enzyme Activity

SGC $=$ Sample Glucose Concentration

$\mathrm{HT}=$ Hydrolysis Time

The unit of the enzymatic activity of glucose produced per minute unit $\left(\mathrm{UGl} \mathrm{h}^{-1}\right)$ can be defined as micromoles of glucose produced per hour at $37^{\circ} \mathrm{C}, \mathrm{pH} 6.5$ and initial lactose concentration (1\%).

After that, the percentage of hydrolysis was calculated as follows (Equation 2):

$\%$ hydrolysis $=(\mathrm{SGC} \times 2 \div 1000) \div \mathrm{Lac} \times 100$

Where:

$\%$ hydrolysis $=$ Percentage of lactose hydrolysis

SGC $=$ Sample Glucose Concentration

$\mathrm{Lac}=$ Initial concentration of lactose 


\subsection{Experimental design for the determination of Beta-galactosidase activity}

Enzymatic determination of lactose hydrolysis, for both permeabilized cells and concentrated enzyme, the experiments were carried out according to the Design of Box-Behnken with three independent variables at three levels $(-1,0,1)$, see Table 1 and Table 2 (Box \& Behnken, 1961). The tested variables were: $\mathrm{pH}$, temperature $\left({ }^{\circ} \mathrm{C}\right)$ and enzyme concentration $(\%)$ - v/v. Based on this, preliminary experiments were performed to obtain an in-depth knowledge of the process, enabling the selection of the best range for developing a design and eventually arriving at the global optimum for high activity of beta-galactosidase through permeabilized cells of SF IZ 275 and enzyme concentrated.
Data analysis was performed with the available statistical program "Statistic 6.0".

The response surface plots used to determine the optimum level of the significant variables for maximal beta-galactosidase activity is shown in Figure 1 and 2 for concentrated enzyme extracted and permeabilized yeast cells, respectively.

\section{Results and discussion}

The Box-Benhken Design (BBD) was used to evaluate the effects among the significant variables and determine their optimal values. BBD is used to reduce the number of experimental runs and increase response efficiency. BBD has been applied

Table 1. Box-Behnken Design used to determine the $\mathrm{pH}$, temperature and enzyme concentration (\%) - v/v, on the beta-galactosidase activity of concentrated enzyme extracted from Saccharomyces fragilis IZ 275.

\begin{tabular}{|c|c|c|c|c|c|}
\hline \multirow{2}{*}{ Run } & \multicolumn{3}{|c|}{ Coded variables } & \multicolumn{2}{|c|}{ Beta-galactosidase activity $\left(\mathrm{UGli} \mathrm{h}^{-1}\right)$} \\
\hline & $\mathrm{X}_{1}$ & $\mathrm{X}_{2}$ & $\mathrm{X}_{3}$ & Experimental & Predictive \\
\hline 1 & -1 & -1 & -1 & 0.16 & 1.81 \\
\hline 2 & -1 & 0 & 1 & 0.41 & -3.63 \\
\hline 3 & -1 & 1 & 0 & 1.55 & 3.95 \\
\hline 4 & 0 & -1 & 1 & 55.67 & 58.06 \\
\hline 5 & 0 & 0 & 0 & 63.18 & 64.83 \\
\hline 6 & 0 & 1 & -1 & 72.50 & 68.45 \\
\hline 7 & 1 & -1 & 0 & 42.98 & 38.94 \\
\hline 8 & 1 & 0 & -1 & 39.36 & 41.75 \\
\hline \multirow[t]{2}{*}{9} & 1 & 1 & 1 & 35.47 & 37.12 \\
\hline & \multicolumn{5}{|c|}{ Decoded variables } \\
\hline & \multicolumn{2}{|c|}{$\mathrm{X}_{1}$} & & \multicolumn{2}{|c|}{$\mathrm{X}_{3}$} \\
\hline & \multicolumn{2}{|c|}{$\mathrm{pH}$} & Tem & \multicolumn{2}{|c|}{ Enzyme concentration (\%) } \\
\hline & \multicolumn{2}{|c|}{5.0} & & \multicolumn{2}{|c|}{3} \\
\hline & \multicolumn{2}{|c|}{6.0} & & \multicolumn{2}{|c|}{4} \\
\hline & \multicolumn{2}{|c|}{7.0} & & \multicolumn{2}{|c|}{5} \\
\hline
\end{tabular}

Table 2. The Box-Behnken Design used to determine the $\mathrm{pH}$, temperature and enzyme concentration (\%) - v/v, on the beta-galactosidase activity of permeabilized cells of Saccharomyces fragilis IZ 275.

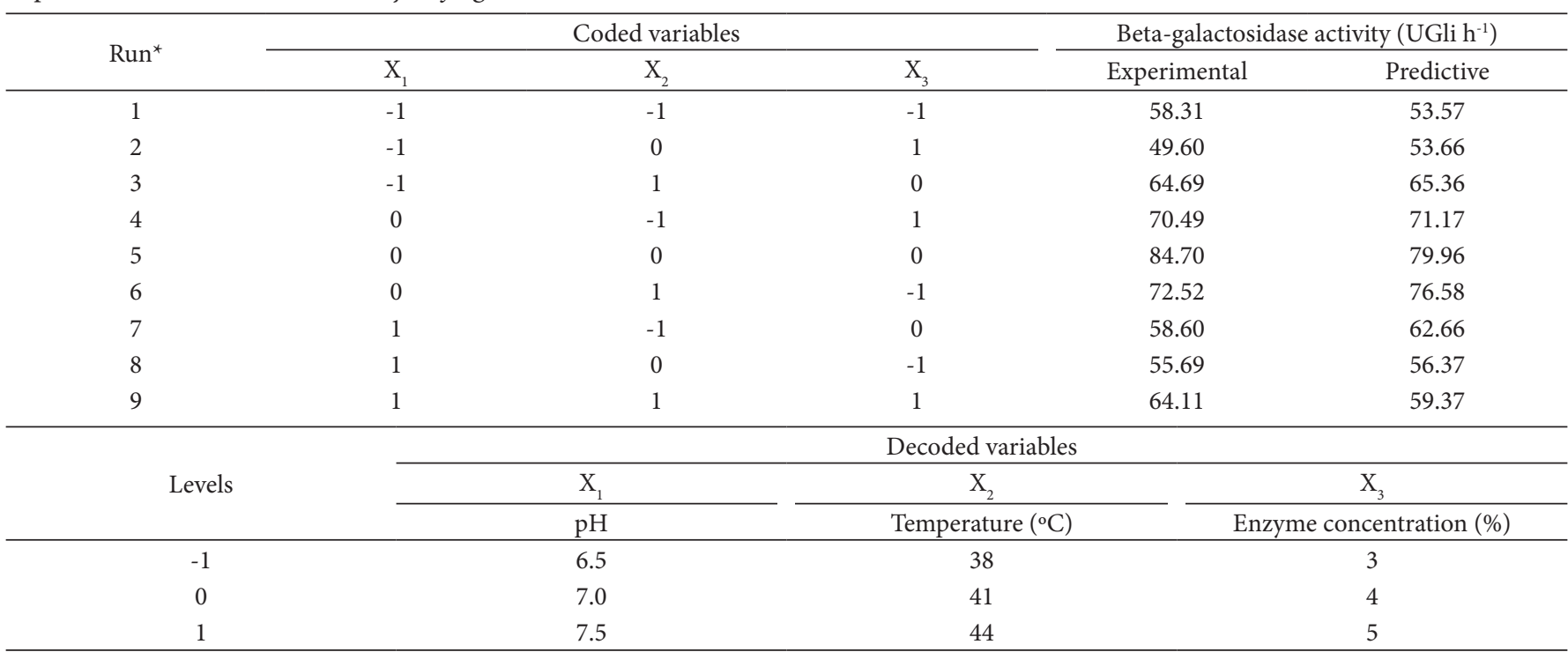

${ }^{\star}$ Run was randomly. 


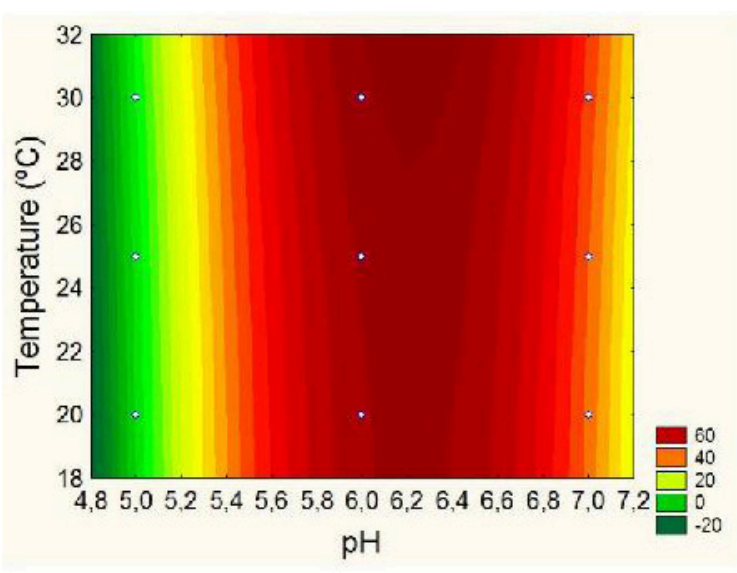

a

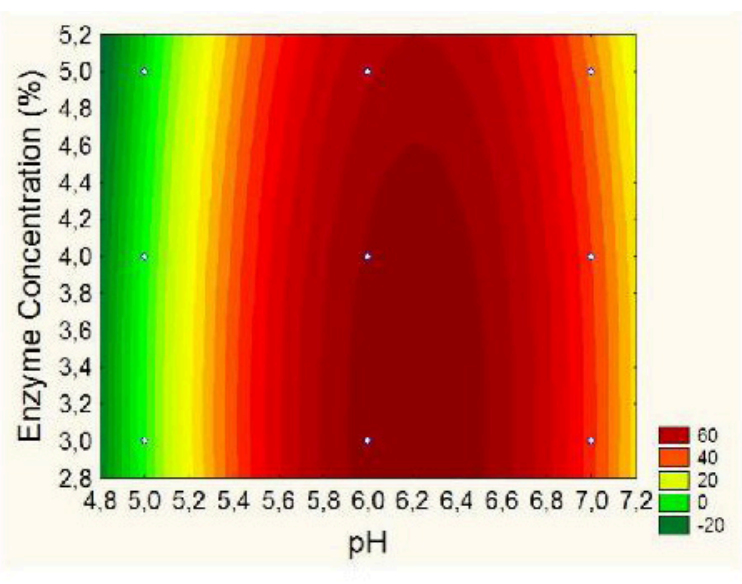

b

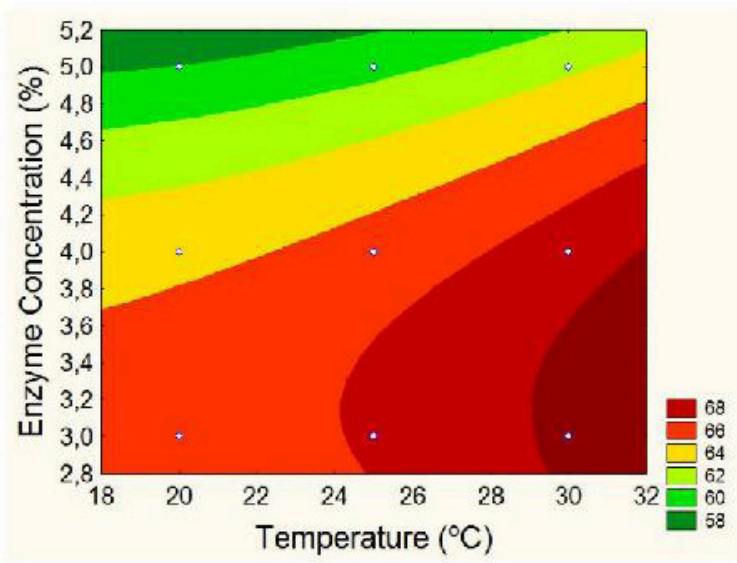

C

Figure 1. Response surface showing the effect of the temperature, ethanol concentration and time reaction on beta-galactosidase activity $\left(\mu \mathrm{mol} \mathrm{Gli} \mathrm{h}^{-1}\right)$ of concentrated beta-galactosidase extracted from Saccharomyces fragilis IZ 275 cells.

and considered to be a very efficient statistical experimental design tool in optimization process (Gámiz-Gracia et al., 2003). Tables 1 and 2 shows the experimental conditions for the batch runs and the corresponding responses, along with both experimental and predicted values of responses in terms of enzyme activity for concentrated enzyme and permeabilized cells of Sacharomyces fragilis IZ 275, respectively.

The determination of the enzymatic activity for CBG and PC was carried out to find the optimal values of independent variables ( $\mathrm{pH}$, temperature and enzyme concentration), which would give maximum lactose hydrolysis by beta-galactosidase activity. Based on the Box-Benhken Design (BBD), the experimental response of beta-galactosidase activity, for concentrated beta-galactosidase, under each set of condition were determined and compared with the corresponding predicted response (Table 1). The maximum experimental value for beta-galactosidase activity was $72.50 \mathrm{UGli} \mathrm{h}^{-1}$ while the value of predicted response was $68.45 \mathrm{UGli} \mathrm{h}^{-1}$. The coefficient of determination $\left(\mathrm{R}^{2}\right)$ of the model was 0.98806 , which indicated that the model adequately represented the real relationship between the variables under consideration. An $\mathrm{R}^{2}$ value of 0.98806 means that $98.88 \%$ of the variability in the experimental and predicted response was explained by the model, which is acceptable for biological system and only $1.12 \%$ was as a result of chance. Approximately $98.9 \%$ of validity was observed, indicating that the model show an adequate prediction on the beta-galactosidase activity. The great correlation between the experimental and predicted response indicates the appropriateness of the experimental design. The maximum beta-galactosidase activity (72.50 $\mathrm{UGli} \mathrm{h}^{-1}$ ) was observed in the following condition, $\mathrm{pH} 6.0,30{ }^{\circ} \mathrm{C}$ and $3 \%$ of enzyme concentration ( $/ \mathrm{v})$, see Table 1 . This enzymatic beta-galactosidase activity of $72.50 \mathrm{UGli} \mathrm{h}^{-1}$ corresponds to $63 \%$ of lactose hydrolyzed by the enzyme.

Based on the results for high beta-galactosidase activity from concentrated enzyme extracted of SF IZ 275, the linear effect of $\mathrm{pH}$ was significant $(\mathrm{p}<0.05)$, indicating the concentration value for the highest design limit $(\mathrm{pH}$ 6.0). The linear and quadratic effects of the temperature and enzyme concentration were not significant $(\mathrm{p}>0.05)$, indicating that temperature and enzyme concentration values for the smaller range $20-25^{\circ} \mathrm{C}$ and $3-4 \%$, respectively showed to be sufficient for the minimal limit of beta-galactosidase activity. 


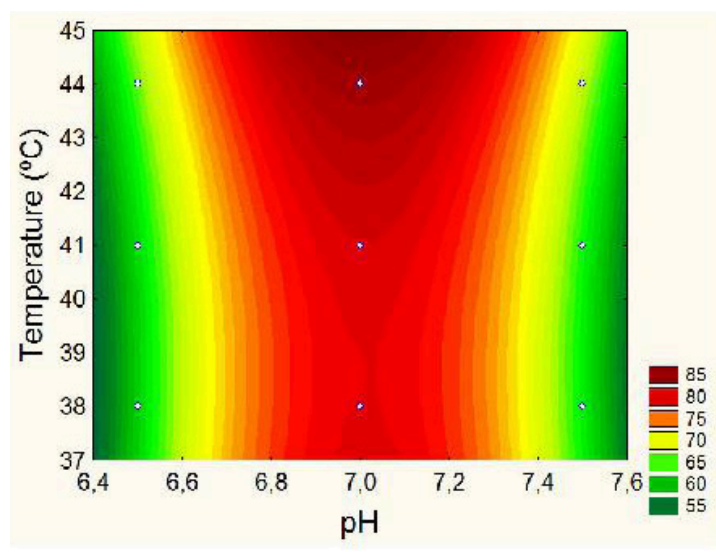

a

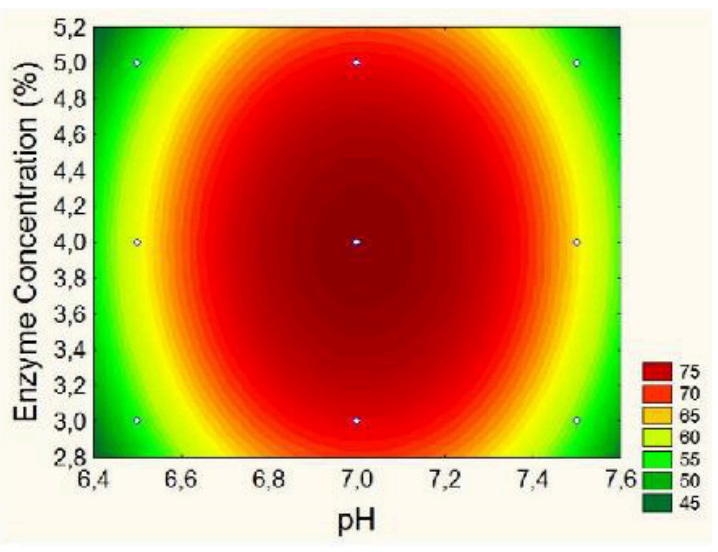

b

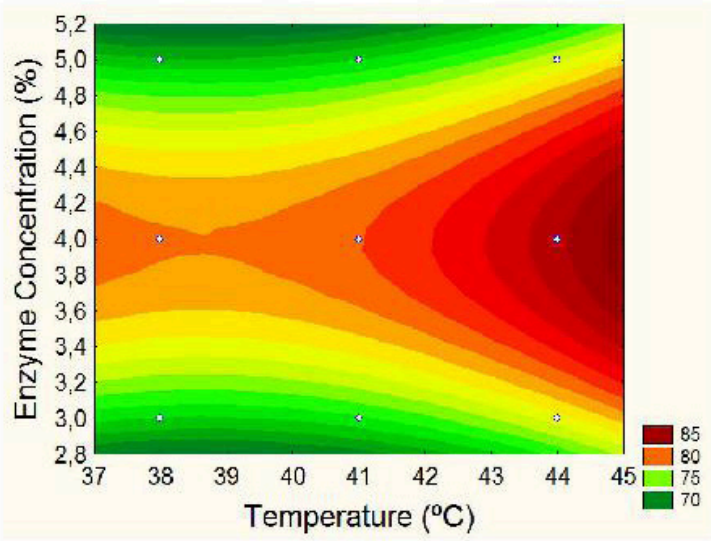

C

Figure 2. Response surface showing the effect of temperature, ethanol concentration andtime reaction on beta-galactosidase activity $\left(\mu \mathrm{mol} G\right.$ li $\mathrm{h}^{-1}$ ) of Saccharomyces fragilis IZ 275 permeabilized cells.

Based on the Box-Benhken Design (BBD), the experimental response of beta-galactosidase activity, for permeabilized cells, under each set of condition tested were determined and compared with the corresponding predicted response according to the model (Table 2). The maximum experimental value obtained for beta-galactosidase activity was $84.70 \mathrm{UGli} \mathrm{h}^{-1}$ while the predicted response was $79.96 \mathrm{UGli} \mathrm{h}^{-1}$. The coefficient of determination $\left(\mathrm{R}^{2}\right)$ of the model was 0.86581 , which indicated good relationship between the variables under consideration. An $R^{2}$ value of 0.86581 means that $86.6 \%$ of the variability was explained by the model, which is acceptable for biological system and only $13.4 \%$ was as a result of chance. Approximately $87.0 \%$ of validity was observed, indicating the model represent an adequate prediction on the enzyme activity. The close correlation between the experimental and predicted response indicates the appropriateness of the experimental design tested. The maximum beta-galactosidase activity $\left(84.70 \mathrm{UGli} \mathrm{h}^{-1}\right)$ was obtained in the following condition, $\mathrm{pH} 7.0,44{ }^{\circ} \mathrm{C}$ and $4 \%$ of enzyme concentration (v/v), see Table 2 . This enzymatic beta-galactosidase activity of $84.70 \mathrm{UGli} \mathrm{h}^{-1}$ corresponds to $73 \%$ of lactose hydrolyzed by the enzyme.
The results for high beta-galactosidase activity from SF IZ 275 permeabilized cells shows that the linear effect of temperature was significant $(\mathrm{p}<0.05)$, indicating that this variable has a positive effect on the beta-galactosidase activity (data not show). Thus, the temperature was established in the highest limit level $\left(44^{\circ} \mathrm{C}\right)$. The linear and quadratic effects of the $\mathrm{pH}$ and enzyme concentration were not significant ( $p>0.05$ ), indicating that this variables has a negative effect on the beta-galactosidase activity (data not show) so, the levels of $\mathrm{pH}$ and enzyme concentration was established in the low range limit, 6.5-7.0 and 3-4\%, respectively so, proving to be sufficient for the process.

\subsection{Determination of the concentrated beta-galactosidase extracted and Saccharomyces fragilis IZ 275 permeabilized cells}

In order to determine the ranges of the tested variables, $\mathrm{pH}$, temperature and enzyme concentration that influence beta-galactosidase activity from concentrated beta-galactosidase extracted and SF IZ 275 permeabilized cells, effects analysis was performed using surface methodology and response, see 
below in Figures 1 and 2, respectively. The response surfaces for beta-galactosidase activity of the concentrated beta-galactosidase extracted, evaluating the variables: $\mathrm{pH}$, temperature and enzyme concentration are shown in the Figure 1.

Figure 1a shows the effects of temperature and $\mathrm{pH}$ variables on beta-galactosidase activity. Temperature and $\mathrm{pH}$ ranging from low until high values of the process showed the high beta-galactosidase activity. The higher beta-galactosidase activity was obtained in the range of $25-30^{\circ} \mathrm{C}$ and $\mathrm{pH}$ between 6.0-7.0. Figure $1 \mathrm{~b}$ shows the response surface as a function of enzyme concentration and $\mathrm{pH}$. Changes in the enzyme concentration does not significantly affect the response of the surface. There is a dependence of beta-galactosidase activity on the $\mathrm{pH}$ ranging from 5.0-7.0. A maximum beta-galactosidase activity of $72.50 \mathrm{UGli} \mathrm{h}^{-1}$ was obtained in the following conditions: $\mathrm{pH} 6.0$, at $30^{\circ} \mathrm{C}$ with $3 \%$ enzyme concentration. Figure $1 \mathrm{c}$ shows that for maximum enzymatic activity the enzyme concentration should be in the range of $3-4 \%$ and the temperature ranging from $25-30{ }^{\circ} \mathrm{C}$, while out of these range a significant decrease of beta-galactosidase activity can be observed. This confirms that the range of the variables tested, in the experimental design, were properly defined thus obtaining good responses of enzymatic activity.

The response surfaces of beta-galactosidase activity in permeabilized cells of Saccharomyces fragilis IZ 275, evaluating the variables $\mathrm{pH}$, temperature and enzyme concentration are shown in Figure 2.

Figure 2 a shows the relationship between temperature and $\mathrm{pH}$ in the beta-galactosidase activity of yeast permeabilized cells. Temperature ranging from middle $\left(35^{\circ} \mathrm{C}\right)$ until high $\left(40{ }^{\circ} \mathrm{C}\right)$ values of process and $\mathrm{pH}$ in the middle (7.0) value, reached the high enzyme activity. The beta-galactosidase activity of yeast permeabilized cells was higher in a temperature of 41 to $44{ }^{\circ} \mathrm{C}$ and $\mathrm{pH}$ 7.0. Figure $1 \mathrm{~b}$ shows the response surface relating the enzyme concentration and $\mathrm{pH}$. In this case the enzyme concentration does not significantly affect the response surface in the experimental design. Based on the results, there is a dependence of beta-galactosidase activity on the $\mathrm{pH}$ value (7.0). A maximum beta-galactosidase activity of $84.70 \mathrm{UGli} \mathrm{h}^{-1}$ was obtained in the following conditions: $\mathrm{pH} 7.0$, at $44{ }^{\circ} \mathrm{C}$ with $4 \%$ enzyme concentration. Figure $1 \mathrm{c}$ showed high beta-galactosidase activity within the range of 3-5\% enzyme concentrations and temperature at higher values than $40^{\circ} \mathrm{C}$. Values outside this range showed low efficiency in the enzymatic activity. This confirms that the range of the choosed variables, in the experimental design, were consistent to obtain high enzymatic activity.

Based on the results obtained, for the concentrated beta-galactosidase the percentage of hydrolysis was $63 \%$, and for the permeabilized cell the percentage was $73 \%$. Previous experiments have shown that when the SF IZ 275 cell is permeabilized, the beta-galactosidase present inside it does not leave the cell, remaining intracellular. Taking into account that the permeabilization creates pores in the cell wall and they do not leave the cell, it can be affirmed that in these experimental conditions the enzymatic activity detected in the permeabilized cells is $100 \%$. Then, by comparing the lactose hydrolysis of the concentrated beta-galactosidase and the permeabilized cell, the permeabilized cell obtained an activity of approximately $14 \%$ greater than the concentrated beta-galactosidase under the experimental conditions tested.

\section{Conclusion}

For the determination of the beta-galactosidase activity from Saccharomyces fragilis IZ 275, the cells need to be permeabilized. With permeabilized yeast cells the activity can be determined in two ways. The first method used for beta-galactosidase determination is by a sintetic substrate called ONPG, which a crude extract is prepared in which the enzymatic activity is quantified according to the total substrate bound to the enzyme. The second method, used for beta-galactosidase determination is by lactose hydrolysis by the permeabilized cells, in which the enzymatic activity is quantified according to the effective hydrolytic capacity of the enzyme on the substrate.

The response surface proved to be a powerful tool for bioprocess optimization which can predict the region of the optimum conditions for obtaining high enzymatic activity. The high enzyme activity of $72.50 \mathrm{UGli} \mathrm{h}^{-1}$, for concentrated beta-galactosidase extracted, was reached in $\mathrm{pH} 6.0$, at $30^{\circ} \mathrm{C}$ and $3 \%$ enzyme concentration $(\mathrm{v} / \mathrm{v})$. And the maximum enzyme activity of $84.70 \mathrm{UGli} \mathrm{h}^{-1}$, for permeabilized cells, was reached in $\mathrm{pH} 7.0$, at $44^{\circ} \mathrm{C}$ and $4 \%$ enzyme concentration (v/v). Permeabilized Saccharomyces fragilis IZ 275 cells retained enzyme activity suggesting that these permeabilized cells could be used as a source of biocatalyst for different applications. Furthermore, permeabilized yeast cells can be used to overcome the problems and costs associated with enzyme extraction and purification from yeast cells and in the development of a low-cost technology for biotechnological application.

\section{Acknowledgements}

The authors would like to thank Coordenação de Aperfeiçoamento de Pessoal de Nível Superior - CAPES/Brazil for the financial support, and KROTON/UNOPAR for school and masterships.

\section{References}

Ansari, S. A., \& Satar, R. (2012). Recombinant $\beta$-galactosidases - Past, present and future: A mini review. Journal of Molecular Catalysis. $B$, Enzymatic, 81, 1-6. http://dx.doi.org/10.1016/j.molcatb.2012.04.012.

Box, G. E. P., \& Behnken, D. W. (1961). Some new three level designs for the study of quantitative variables. Technometrics, 2(4), 455-475. http://dx.doi.org/10.1080/00401706.1960.10489912.

Brasil, Ministério da Saúde, Agência Nacional de Vigilância Sanitária. (2006 Novembro 14). Aprova o "Regulamento Técnico sobre Enzimas e Preparações Enzimáticas para Uso na Produção de Alimentos Destinados ao Consumo Humano“ (Resolução RDC n 205). Diário Oficial [da] República Federativa do Brasil.

Colognesi, G. O. S., Pedrinho, D. R., Sandra, G., Morioka, L. R. I., \& Suguimoto, H. H. (2017). Fermentation of deproteinized cheese whey by Saccharomyces fragilis IZ 275 for ethanol production on pilot scale. African Journal of Biotechnology, 16(42), 2043-2049. http://dx.doi.org/10.5897/AJB2016.15705.

Dagbagli, S., \& Goksungur, Y. (2008). Optimization of $\beta$-galactosidase production using Kluyveromyces lactis NRRL Y-8279 by response 
surface methodology. Electronic Journal of Biotechnology, 11(4), 11-12. http://dx.doi.org/10.2225/vol11-issue4-fulltext-12.

Demirhan, E., Apar, D. K., \& Özbek, B. (2010). A modelling study on hydrolysis of whey lactose and stability of $\beta$-galactosidase. Korean Journal of Chemical Engineering, 27(2), 536-545. http://dx.doi. org/10.1007/s11814-010-0062-5.

Di Serio, M., Maturo, C., De Alteriis, E., Parascandola, P., Tesser, R., \& Santacesaria, E. (2003). Lactose hydrolysis by immobilized $\beta$-galactosidase: the effect of the supports and kinetics. Catalysis Today, 79-80, 333-339. http://dx.doi.org/10.1016/S09205861(03)00059-2.

Domingues, L., Guimarães, P. M. R., \& Oliveira, C. (2010). Metabolic engineering of Saccharomyces cerevisiae for lactose/whey fermentation. Bioengineered Bugs, 1(3), 164-171. http://dx.doi.org/10.4161/ bbug.1.3.10619. PMid:21326922.

Dutra Rosolen, M., Gennari, A., Volpato, G., \& Volken de Souza, C. F. (2015). Lactose hydrolysis in milk and dairy whey using microbial $\beta$-galactosidases. Enzyme Research, 2015, 1-7. http://dx.doi. org/10.1155/2015/806240. PMid:26587283.

Florêncio, I. M., Florentino, E. R., Silva, F. L. H., Martins, R. S., Cavalcanti, M. T., \& Gomes, J. P. (2013). Production of ethanol from industrial whey. Brazilian Journal of Agricultural and Environmental Engineering, 17, 1088-1092.

Gámiz-Gracia, L., Cuadros-Rodríguez, L., Almansa-López, E. J., SotoChinchilla, J. M., \& García-Campaña, A. (2003). Use of highly efficient Draper-Lin small composite designs in the formal optimization of both operational and chemical crucial variables affecting a FIAchemiluminescence detection system. Talanta, 60(2-3), 523-534. http://dx.doi.org/10.1016/S0039-9140(03)00107-3. PMid:18969074.

Hatzinikolaou, D. G., Katsifas, E., Mamma, D., Karagouni, A. D., Christakopoulos, P., \& Kekos, D. (2005). Modeling of the simultaneous hydrolysis-ultrafiltration whey permeate by a thermostable $\beta$-galactosidase from A. oryzae. Biochemical Engineering Journal, 24(2), 161-172. http://dx.doi.org/10.1016/j.bej.2005.02.011.

Husain, Q. (2010). $\beta$ Galactosidases and their potencial applications: a review. Critical Reviews in Biotechnology, 30(1), 41-62. http://dx.doi. org/10.3109/07388550903330497. PMid:20143935.

Marcel, J. R. P., \& Passos, F. M. L. (2011). Solvent extraction of $\beta$-galactosidase from Kluyveromyces lactis yields a stable highly active enzyme preparation. Journal of Food Biochemistry, 35(1), 323-336. http://dx.doi.org/10.1111/j.1745-4514.2010.00384.x.

Morioka, L. R. I., Colognesi, G. O., \& Suguimoto, H. H. (2016). Permeabilization of Saccharomyces fragilis IZ 275 cells with ethanol to obtain a biocatalyst with lactose hydrolysis capacityv. Acta Scientiarum. Biological Sciences, 38(2), 149-155. http://dx.doi. org/10.4025/actascibiolsci.v38i2.29220.

Ordoñez, J. A. (2005). Food Technology - Food Components and Processes (Vol. 1). Porto Alegre: Artmed Bookman.

Roy, I., \& Gupta, M. N. (2003). Lactose hydrolysis by Lactosym ${ }^{\mathrm{TM}}$ immobilized on cellulose beads in batch and fluidized bed modes. Process Biochemistry, 39(3), 325-332. http://dx.doi.org/10.1016/ S0032-9592(03)00086-4.

Şener, N., Kılıç Apar, D., \& Özbek, B. (2006). A modelling study on milk lactose hydrolysis and $\beta$-galactosidase stability under sonication. Process Biochemistry, 41(7), 1493-1500. http://dx.doi.org/10.1016/j. procbio.2006.02.008.

Torres, P., \& Batista-Vieira, F. (2012). Improved biocatalysts based on Bacillus circulans $\beta$-galactosidase immobilized onto epoxy-activated acrylic supports: Applications in whey processing. Journal of Molecular Catalysis. B, Enzymatic, 83, 57-64. http://dx.doi.org/10.1016/j. molcatb.2012.07.004. 